\title{
Review Paper: A Review of Selected Factors Affecting Gait Symmetry
}

\author{
Alireza Nasirzade ${ }^{\text {* }}$, Heydar Sadeghi ${ }^{1}$, Hamid Reza Mokhtarinia' ${ }^{2}$ Abbas Rahimi ${ }^{3}$ \\ 1. Department of Sports Biomechanics, Faculty of Physical Education and Sport Sciences, Kharazmi University, Tehran, Iran. \\ 2. Department of Physiotherapy, University of Social Welfare and Rehabilitation Sciences, Tehran, Iran. \\ 3. Department of Physiotherapy, School of Rehabilitation, Shahid Beheshti University of Medical Sciences, Tehran, Iran.
}

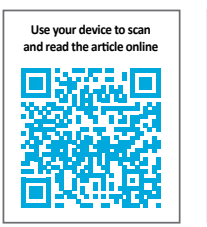

Citration: Nasirzade A, Sadeghi H, Mokhtarinia HR, Rahimi A. A Review of Selected Factors Affecting Gait Symmetry. Physical Treatments. 2017; 7(1):3-12. https://doi.org/10.29252/NRIP.PTJ.7.1.3

https://doi.org/10.29252/NRIP.PTJ.7.1.3

Article info:

Received: 13 Nov. 2016

Accepted: 04 Feb. 2017
Keywords:

Biomechanics, Gait symmetry, Walking speed, Age, Pathology

\begin{abstract}
A B S T RA C T
Purpose: Because walking is the main activity of humans for movement, many research studies have been conducted to understand its details. One of the main issues in this regard is gait symmetry and the effect of various factors on it. Accordingly, the present study aimed to review the selected factors affecting gait symmetry.

Methods: A literature review was performed on articles published from 2000 to 2016 using Science Direct, Google scholar, PubMed, Ovid Medline, Scopus and Medline databases. The search keywords were "gait asymmetry", "bilateral coordination", "bilateral asymmetry", "limb dominance", "laterality", "limb preference" and "performance asymmetry."

Results: A total of 60 scientific articles were selected according to the research criteria by searching the relevant articles published from 2000 to 2016 in reliable scientific databases.

Conclusion: A review of the previous studies shows that walking in normal people is asymmetric in terms of the lower limb function. Also, limb disorder due to the illness and or disorder creates gait asymmetry. Therefore, regaining perfect symmetry or decreasing gait asymmetry by exercise and intervention in such individuals is considered a method to examine the success of rehabilitation process. However, as factors like movement speed and age can affect gait asymmetry, they should be controlled during the examination of gait asymmetry. Moreover, this information could be useful for gait assessment, clinical prescriptions for patients with abnormalities, designing orthosis and prosthesis, as well as improving the performance of athletes.
\end{abstract}

\section{Introduction}

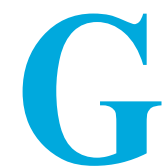

ait symmetry and limbs coordination are necessary to achieve a balanced movement [1]. In biomechanical research re- ports, the symmetry of lower limbs is a fundamental presumption, so that the data collected, and consequently, the complexity of general data and their analysis would be significantly reduced assuming the lower limb symmetry [1]. Regardless of the research method, the pres-

\footnotetext{
* Corresponding Author:

Alireza Nasirzade, PhD Candidate

Address: Department of Sports Biomechanics, Faculty of Physical Education and Sport Sciences, Kharazmi University, Tehran, Iran

Phone: +98 (935) 9515557

E-mail: alireza.nasirzade@gmail.com
} 
ence or absence of gait symmetry is one of the key issues in this field, and still a matter of controversy.

From clinical perspective, asymmetry, as a pathologic factor, is an important study subject. Furthermore, gait symmetry is considered an important factor for assessing the functional inefficiency, especially in patients with different abnormalities. As a result, achieving symmetry or reducing the gait asymmetry in people with any disorder before and after rehabilitation has been used as a method for assessing the effectiveness of the therapeutic model [2 -6]. Ellis et al. [7] reported that increased gait asymmetry would increase metabolic and mechanical costs, suggesting the gait symmetry as the best prescription for healthy people. Thus, achieving full gait symmetry in most cases is an important target for physiotherapy in people with various diseases and functional anomalies $[5,8]$, although many other papers have not supported this claim [9, 10]. However, many scholars have discussed the issue of gait symmetry in people with and without various diseases and anomalies.

In this context, one of the issues studied by numerous papers is how the gait symmetry is affected by different factors. Meanwhile, the effect of factors such as age, gender, walking speed, as well as various anomalies and diseases, have been considered [1, 11]. However, as different methods have been used to examine gait symmetry, there is no consensus among the various articles in this regard, and some contradictory results have been presented in some cases [11]. Accordingly, as no review study has been performed to examine the effect of these factors on gait symmetry, the present review study aimed at examining the concept of gait symmetry and also the effects of various factors on it, including diseases or anomalies, movement speed, age, and gender.

\section{Materials and Methods}

This is a review study. Accordingly, a literature research was performed on articles published from 2000 to 2016 using Science Direct, Google scholar, PubMed, Ovid Medline, Scopus and Medline databases. The search keywords were "gait asymmetry", "bilateral coordination", "bilateral asymmetry", "limb dominance", "laterality", "limb preference", and "performance asymmetry" (Papers published before 2000 has been studied in the review by Sadeghi et al.) [1].

A preliminary general search resulted in about 2500 relevant articles. After reviewing the titles and abstracts, 315 articles were selected for the next stage. Finally, af ter reading the full texts and taking into account indicators such as simultaneous evaluation of the lower limbs' function during the evaluation, training or rehabilitation protocols, the study of the effect of different factors on gait symmetry and indexing the article in reliable databases, 60 papers were selected as final papers for the present review study. The summary of this process is presented in Figure 1.

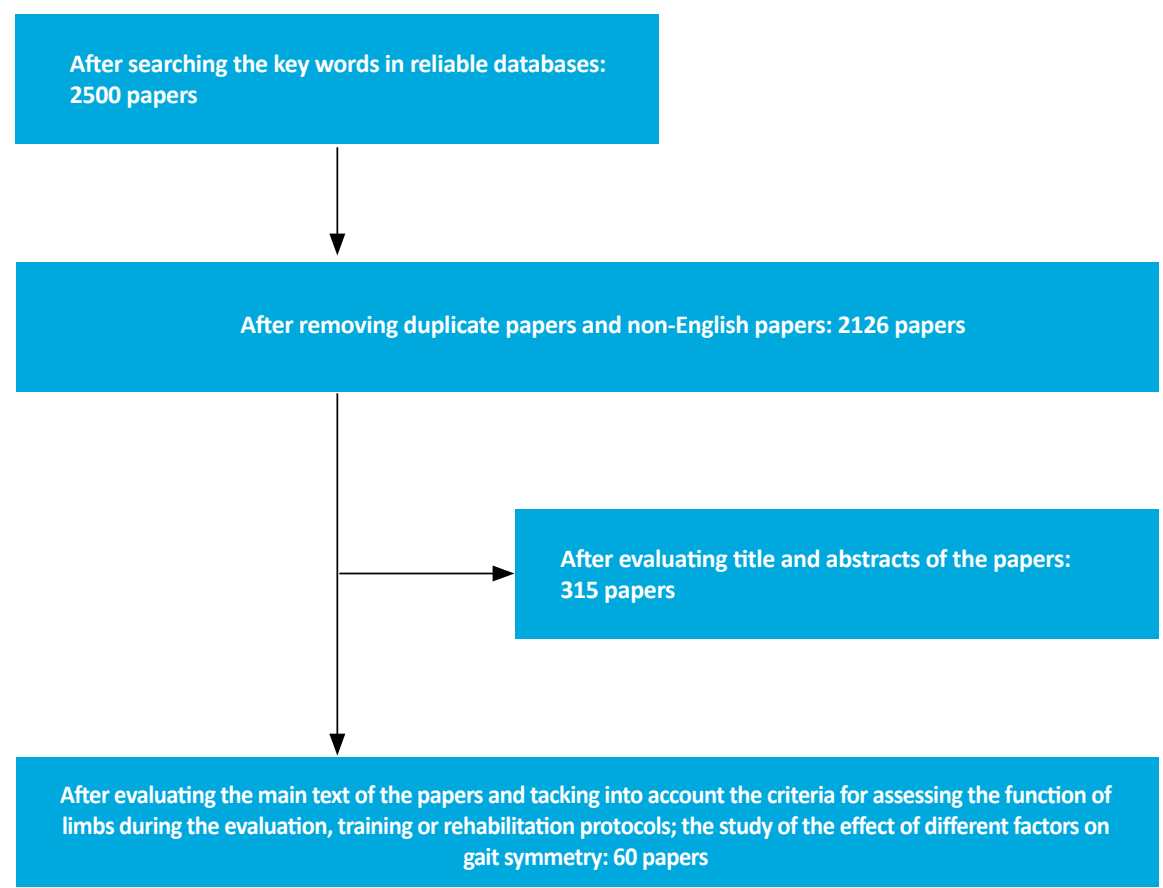

Figure 1. The process of review study 


\section{Results}

\section{Definition of gait symmetry}

Given that numerous articles have presented different definitions and criteria for recognizing gait symmetry, a general approach should be provided. In this regard, gait symmetry is defined as a complete harmony between the activities of the lower limbs during walking [1]. However, some studies consider gait symmetry when the values measured for the lateral limbs are the same, or their differences are not statistically significant [10]. Nevertheless, despite the different definitions, the main idea for describing the concept of gait symmetry is when the bilateral limbs have similar activities $[1,9]$.

\section{Gait symmetry or asymmetry}

Sadeghi et al. and Nasirzadeh et al. [1, 11] prepared two review articles about the symmetry of the lower limbs during walking. Based on their studies, the performance of lower limbs in healthy people during walking at normal speed is naturally asymmetric, resulting from different functions performed by the lower limbs (Table 1). In these conditions, given that gait symmetry is the ideal state of walking for healthy people [7], the created asymmetry between the lower limbs depends on the conditions. Symmetry seems to be desirable because it facilitates control strategies. However, gait asymmetry is also needed to restore stability against internal and external disturbances [12]. Anyhow, further research is necessary to understand the main causes of gait asymmetry in healthy people.

\section{The effect of different factors on gait symmetry}

In this section, we examine four important factors affecting gait symmetry, i.e. disease and anomalies, movement speed, age, and gender.

The effect of disease and anomalies on gait symmetry

Achieving full gait symmetry is often an important target for physiotherapy in people with various diseases and functional anomalies [5, 8]. Examples of clinical trials include a comparison between dysfunctional gait and normal people with hypothetical gait symmetry [13]. A

Table 1. Studies on the lower limbs symmetry during walking (from 2000 onward)

\begin{tabular}{|c|c|c|c|c|c|}
\hline Research Fellow & Subjects & Protocol & Variables & Results & Conclusion \\
\hline $\begin{array}{l}\text { Sadeghi, } 2003 \\
{[9]}\end{array}$ & $\begin{array}{l}\text { Healthy young } \\
\text { men with } \\
\text { imean(SD) age: } \\
25.3(4.1) \text { years }\end{array}$ & $\begin{array}{l}\text { Walking at } \\
\text { the desired } \\
\text { speed }\end{array}$ & $\begin{array}{l}\text { Muscular } \\
\text { torque }\end{array}$ & $\begin{array}{l}\text { Different functional tasks identified for joints and their } \\
\text { similarity with the lower limbs }\end{array}$ & $\begin{array}{l}\text { Local asymme- } \\
\text { try and lower- } \\
\text { limb symmetry } \\
\text { of organs }\end{array}$ \\
\hline $\begin{array}{l}\text { Goble et al., } \\
2003 \text { [13] }\end{array}$ & $\begin{array}{l}\text { Healthy young } \\
\text { men with } \\
\text { mean(SD) age: } \\
23.8(2.2) \text { years }\end{array}$ & $\begin{array}{l}\text { Walk } \\
\text { at three } \\
\text { speeds } \\
\text { (slow, } \\
\text { normal and } \\
\text { fast) }\end{array}$ & $\begin{array}{l}\text { Ground Reac- } \\
\text { tion Force } \\
\text { (GRF) }\end{array}$ & $\begin{array}{l}\text { Improvement of gait symmetry by increasing the walking } \\
\text { speed }\end{array}$ & 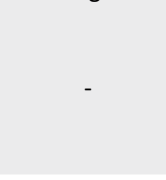 \\
\hline $\begin{array}{l}\text { Nolan et al., } \\
2003[14]\end{array}$ & $\begin{array}{l}\text { Young subjects } \\
\text { with lower } \\
\text { limb amputa- } \\
\text { tion }\end{array}$ & $\begin{array}{l}\text { Walking at } 4 \\
\text { different } \\
\text { speeds }\end{array}$ & $\begin{array}{l}\text { Kinematics } \\
\text { and vGRF }\end{array}$ & $\begin{array}{l}\text { Reduced temporal asymmetry and increased vGRF } \\
\text { asymmetry by increasing the walking speed }\end{array}$ & Asymmetry \\
\hline $\begin{array}{l}\text { Hesse et al., } \\
2003[3]\end{array}$ & $\begin{array}{l}\text { Subjects with } \\
\text { arthroplasty of } \\
\text { the hip joint }\end{array}$ & $\begin{array}{l}\text { Walking at } \\
\text { the desired } \\
\text { speed }\end{array}$ & $\begin{array}{l}\text { Kinematics } \\
\text { and EMG }\end{array}$ & $\begin{array}{l}\text { Further reduction in gait asymmetry after body weight } \\
\text { support exercises on treadmill compared to conventional } \\
\text { rehabilitation exercises }\end{array}$ & - \\
\hline $\begin{array}{l}\text { Perttunen et al., } \\
\quad 2004[15]\end{array}$ & $\begin{array}{c}\text { Teen subjects } \\
\text { with mean age: } \\
14.6 \text { years with } \\
\text { different leg } \\
\text { length }\end{array}$ & $\begin{array}{l}\text { Walking at } \\
\text { two normal } \\
\text { and fast } \\
\text { speeds }\end{array}$ & $\begin{array}{l}\text { GRF and plan- } \\
\text { tar pressure } \\
\text { distribution }\end{array}$ & Increased gait asymmetry at higher speeds & Asymmetry \\
\hline $\begin{array}{l}\text { Chockalingam et } \\
\text { al., } 2004 \text { [16] }\end{array}$ & $\begin{array}{l}\text { Teen subjects } \\
\text { with scoliosis }\end{array}$ & $\begin{array}{l}\text { Walking } \\
\text { at normal } \\
\text { speed }\end{array}$ & GRF & $\begin{array}{l}\text { Asymmetry in GRF components between the two lower } \\
\text { limbs and its association with scoliosis abnormality }\end{array}$ & Asymmetry \\
\hline $\begin{array}{l}\text { Diop et al., } 2004 \\
{[6]}\end{array}$ & $\begin{array}{c}\text { Healthy } \\
\text { children aged } \\
\text { 4-10 years old }\end{array}$ & $\begin{array}{l}\text { Walking } \\
\text { at three } \\
\text { different } \\
\text { speeds }\end{array}$ & $\begin{array}{l}\text { Kinematics } \\
\text { and GRF }\end{array}$ & $\begin{array}{l}\text { In these people, walking was asymmetric, and it was not } \\
\text { affected by age and speed }\end{array}$ & Asymmetry \\
\hline $\begin{array}{l}\text { Rodgers et al., } \\
2004 \text { [17] }\end{array}$ & $\begin{array}{l}\text { Elderly subjects } \\
\text { with stroke }\end{array}$ & $\begin{array}{l}\text { Walking at } \\
\text { the desired } \\
\text { speed }\end{array}$ & $\begin{array}{l}\text { Plantar pres- } \\
\text { sure distribu- } \\
\text { tion }\end{array}$ & $\begin{array}{l}\text { Reduced gait at asymmetry by increasing walking speed } \\
\text { in these subjects }\end{array}$ & - \\
\hline
\end{tabular}




\begin{tabular}{|c|c|c|c|c|c|}
\hline Research Fellow & Subjects & Protocol & Variables & Results & Conclusion \\
\hline $\begin{array}{l}\text { Kramers-de } \\
\text { Quervain et } \\
\text { al., } 2004[18]\end{array}$ & $\begin{array}{l}\text { Teen girls with } \\
\text { unknown } \\
\text { scoliosis }\end{array}$ & $\begin{array}{l}\text { Walking at } \\
\text { the desired } \\
\text { speed }\end{array}$ & $\begin{array}{l}\text { Kinematics } \\
\text { and GRF }\end{array}$ & $\begin{array}{l}\text { Symmetry of kinematic parameters in three dimensions, } \\
\text { and the ground reaction force between the two lower } \\
\text { limbs }\end{array}$ & Asymmetry \\
\hline $\begin{array}{l}\text { Plotnik et al., } \\
2005 \text { [19] }\end{array}$ & $\begin{array}{l}\text { Elderly } \\
\text { patients with } \\
\text { Parkinson }\end{array}$ & $\begin{array}{l}\text { Walking at } \\
\text { the desired } \\
\text { speed }\end{array}$ & Kinematics & $\begin{array}{l}\text { Severe asymmetry and disharmony in lower limbs when } \\
\text { walking }\end{array}$ & Asymmetry \\
\hline $\begin{array}{l}\text { Plotnik et } \\
\text { al., } 2007 \text { [20] }\end{array}$ & $\begin{array}{l}\text { Young and } \\
\text { elderly } \\
\text { healthy sub- } \\
\text { jects and el- } \\
\text { derly patients } \\
\text { with Parkinson }\end{array}$ & $\begin{array}{l}\text { Walking at } \\
\text { the desired } \\
\text { speed }\end{array}$ & Kinematics & $\begin{array}{l}\text { The gait asymmetry increases with age, and this asym- } \\
\text { metry gets worse due to Parkinson }\end{array}$ & Asymmetry \\
\hline $\begin{array}{l}\text { Liikavainio et al., } \\
\qquad 2007 \text { [21] }\end{array}$ & $\begin{array}{l}\text { Elderly } \\
\text { patients with } \\
\text { osteoarthritis }\end{array}$ & $\begin{array}{l}\text { Walking } \\
\text { with normal } \\
\text { and fast } \\
\text { speeds }\end{array}$ & $\begin{array}{l}\text { Kinematics } \\
\text { and GRF }\end{array}$ & $\begin{array}{c}\text { No asymmetry was found regarding kinematic and } \\
\text { kinetic variables at the moment of heel contact with the } \\
\text { ground }\end{array}$ & Symmetry \\
\hline $\begin{array}{l}\text { Patterson et al., } \\
\quad 2008[22]\end{array}$ & $\begin{array}{l}\text { Elderly patients } \\
\text { with stroke }\end{array}$ & $\begin{array}{l}\text { Walking at } \\
\text { normal and } \\
\text { fast speeds }\end{array}$ & Kinematics & $\begin{array}{l}\text { Spatial and temporal gait asymmetry, where the tempo- } \\
\text { ral one was intensified by an increase in walking speed }\end{array}$ & Asymmetry \\
\hline $\begin{array}{l}\text { Hodt-Billington } \\
\text { et al., } 2008 \text { [23] }\end{array}$ & $\begin{array}{l}\text { Elderly } \\
\text { subjects with } \\
\text { and without } \\
\text { chronic stroke }\end{array}$ & $\begin{array}{l}\text { Walking } \\
\text { with three } \\
\text { speeds } \\
\text { (slow, } \\
\text { normal, and } \\
\text { fast) }\end{array}$ & Kinematics & $\begin{array}{c}\text { Except for movements of the trunk, other variables did } \\
\text { not have the ability to distinguish between subjects, and } \\
\text { it can be used as a factor for evaluating the patients' gait } \\
\text { asymmetry }\end{array}$ & Asymmetry \\
\hline $\begin{array}{l}\text { Senden et al., } \\
2009[24]\end{array}$ & $\begin{array}{l}\text { Healthy men } \\
\text { and wom- } \\
\text { en aged from } \\
20 \text { to } 86 \text { years }\end{array}$ & $\begin{array}{l}\text { Walking } \\
\text { at normal } \\
\text { speed }\end{array}$ & Kinematics & Gender and age do not affect gait asymmetry & - \\
\hline $\begin{array}{l}\text { Bosch and } \\
\text { Rosenbaum, } \\
2010[25]\end{array}$ & $\begin{array}{l}\text { Healthy chil- } \\
\text { dren }\end{array}$ & $\begin{array}{l}\text { Walking } \\
\text { at normal } \\
\text { speed }\end{array}$ & $\begin{array}{l}\text { Plantar pres- } \\
\text { sure distribu- } \\
\text { tion }\end{array}$ & $\begin{array}{l}\text { At the beginning of walking, children show asymmetric } \\
\text { behavior that decreases with aging }\end{array}$ & Asymmetry \\
\hline $\begin{array}{l}\text { Patterson et } \\
\text { al., } 2010[26]\end{array}$ & $\begin{array}{l}\text { Elderly subjects } \\
\text { with and with- } \\
\text { out stroke }\end{array}$ & $\begin{array}{l}\text { Walking } \\
\text { at normal } \\
\text { speed }\end{array}$ & Kinematics & $\begin{array}{l}\text { By comparing the symmetry indices, none had superior- } \\
\text { ity in the ability to differentiate, however, the symmetry } \\
\text { ratio is recommended for the ease of interpretation }\end{array}$ & - \\
\hline $\begin{array}{l}\text { Seeley et al., } \\
2010[27]\end{array}$ & $\begin{array}{l}\text { Healthy } \\
\text { young sub- } \\
\text { jects with } \\
\text { different lower } \\
\text { limb lengths }\end{array}$ & $\begin{array}{l}\text { Walking } \\
\text { at normal } \\
\text { speed }\end{array}$ & $\begin{array}{l}\text { Kinematics, } \\
\text { torque and } \\
\text { mechanical } \\
\text { power }\end{array}$ & $\begin{array}{l}\text { The gait was asymmetrical in these individuals, and it } \\
\text { increases by intensification of the disorder }\end{array}$ & Asymmetry \\
\hline $\begin{array}{l}\text { Kong et al., } \\
2010[28]\end{array}$ & $\begin{array}{l}\text { Healthy } \\
\text { young subjects }\end{array}$ & $\begin{array}{l}\text { Walking } \\
\text { at normal } \\
\text { speed }\end{array}$ & Kinematics & Physiological fatigue does not affect gait asymmetry & Asymmetry \\
\hline $\begin{array}{l}\text { Lythgo et } \\
\text { al., } 2010 \text { [29] }\end{array}$ & $\begin{array}{l}\text { Healthy } \\
\text { children and } \\
\text { young subjects }\end{array}$ & $\begin{array}{l}\text { Walk } \\
\text { at three } \\
\text { speeds } \\
\text { (slow, } \\
\text { normal and } \\
\text { fast) }\end{array}$ & Kinematics & Walking of healthy children is very symmetrical & Symmetry \\
\hline $\begin{array}{l}\text { Bradley et al., } \\
2012[30]\end{array}$ & $\begin{array}{l}\text { Elderly subjects } \\
\text { with stroke }\end{array}$ & $\begin{array}{l}\text { Walking } \\
\text { with normal } \\
\text { and fast } \\
\text { speeds }\end{array}$ & Kinematics & $\begin{array}{c}\text { There was a correlation between gait asymmetry and } \\
\text { dynamic balance in these people, suggesting that an } \\
\text { increase in their asymmetry puts them at increased risk } \\
\text { of falling }\end{array}$ & - \\
\hline $\begin{array}{l}\text { Patterson et al., } \\
\quad 2012[4]\end{array}$ & $\begin{array}{l}\text { Elderly subjects } \\
\text { with and with- } \\
\text { out stroke }\end{array}$ & $\begin{array}{l}\text { Walking at } \\
\text { the desired } \\
\text { speed }\end{array}$ & Kinematics & $\begin{array}{l}\text { There was no relationship between gait asymmetry and } \\
\text { age or speed for both groups }\end{array}$ & Asymmetry \\
\hline $\begin{array}{l}\text { Chester and Cal- } \\
\text { houn, } 2012[31]\end{array}$ & $\begin{array}{l}\text { Children with } \\
\text { autism }\end{array}$ & $\begin{array}{l}\text { Walking } \\
\text { at normal } \\
\text { speed }\end{array}$ & Kinematics & $\begin{array}{l}\text { There is no difference between these children and } \\
\text { healthy children in terms of symmetrical indicators and } \\
\text { spatial-temporal parameters }\end{array}$ & - \\
\hline $\begin{array}{l}\text { Forczek and } \\
\text { Staszkiewicz, } \\
2012[32]\end{array}$ & $\begin{array}{l}\text { Healthy young } \\
\text { women and } \\
\text { men }\end{array}$ & $\begin{array}{l}\text { Walking at } \\
\text { a constant } \\
\text { speed }\end{array}$ & Kinematics & $\begin{array}{l}\text { Lower limb joints during gait are asymmetrical in } \\
\text { terms of angular changes. There was also a difference } \\
\text { between the asymmetry of angular parameters and } \\
\text { spatial-temporal parameters of both sexes }\end{array}$ & Asymmetry \\
\hline
\end{tabular}




\begin{tabular}{|c|c|c|c|c|c|}
\hline Research Fellow & Subjects & Protocol & Variables & Results & Conclusion \\
\hline $\begin{array}{l}\text { La Roche et al., } \\
2012 \text { [33] }\end{array}$ & $\begin{array}{l}\text { Healthy old } \\
\text { women }\end{array}$ & $\begin{array}{l}\text { Walking } \\
\text { at normal } \\
\text { speed and } \\
\text { maximum } \\
\text { speed }\end{array}$ & $\begin{array}{l}\text { Kinematics } \\
\text { and GRF }\end{array}$ & $\begin{array}{c}\text { Gait asymmetry increases with increasing of knee } \\
\text { extension strength asymmetry which is intensified by } \\
\text { increasing walking speed }\end{array}$ & Asymmetry \\
\hline $\begin{array}{c}\text { Winiarski and } \\
\text { Czamara, } 2012 \\
{[34]}\end{array}$ & $\begin{array}{l}\text { Healthy young } \\
\text { subjects with } \\
\text { anterior cruci- } \\
\text { ate ligament } \\
\text { (ACL) rupture }\end{array}$ & $\begin{array}{l}\text { Walking at } \\
\text { the desired } \\
\text { speed }\end{array}$ & Kinematics & $\begin{array}{c}\text { Significant improvement in asymmetry } \\
\text { indicators of these people after } 12 \text { weeks of physio- } \\
\text { therapy }\end{array}$ & - \\
\hline $\begin{array}{c}\text { Ellis et al., } \\
2013 \text { [7] }\end{array}$ & $\begin{array}{l}\text { Healthy } \\
\text { young subjects }\end{array}$ & $\begin{array}{l}\text { Walking at } \\
\text { a constant } \\
\text { speed }\end{array}$ & Kinematics & $\begin{array}{l}\text { Increased gait asymmetry increases the metabolic and } \\
\text { mechanical costs, and symmetrical gait is recommended } \\
\text { as the most optimal mode for healthy people }\end{array}$ & - \\
\hline $\begin{array}{l}\text { Plotnik et } \\
\text { al., } 2013 \text { [35] }\end{array}$ & $\begin{array}{l}\text { Healthy } \\
\text { young subjects }\end{array}$ & $\begin{array}{l}\text { Walking } \\
\text { at three } \\
\text { speeds } \\
\text { (slow, } \\
\text { normal, and } \\
\text { fast) }\end{array}$ & $\begin{array}{c}\text { Kinematics } \\
\text { and GRF }\end{array}$ & $\begin{array}{l}\text { There was no relationship between walking speed and } \\
\text { its asymmetry }\end{array}$ & Asymmetry \\
\hline $\begin{array}{l}\text { Kobsar et al., } \\
2014[36]\end{array}$ & $\begin{array}{l}\text { Healthy young } \\
\text { and elderly } \\
\text { subjects }\end{array}$ & $\begin{array}{c}\text { Walking at } \\
\text { the desired } \\
\text { speed }\end{array}$ & Kinematics & Gait asymmetry increases with age & Asymmetry \\
\hline $\begin{array}{l}\text { Kobayashi et } \\
\text { al., } 2014 \text { [37] }\end{array}$ & $\begin{array}{l}\text { Healthy young } \\
\text { men and } \\
\text { women }\end{array}$ & $\begin{array}{l}\text { Walking at } \\
\text { the desired } \\
\text { speed }\end{array}$ & Kinematics & $\begin{array}{l}\text { Gait asymmetry increases with age and men are more } \\
\text { asymmetrical than women. The effect of gender on gait } \\
\text { asymmetry was more significant than age }\end{array}$ & Asymmetry \\
\hline $\begin{array}{l}\text { Mahon et al., } \\
2014[38]\end{array}$ & $\begin{array}{l}\text { Elderly subjects } \\
\text { with stroke - } \\
\text { classified into } \\
\text { two groups } \\
\text { based on abil- } \\
\text { ity to walk }\end{array}$ & $\begin{array}{l}\text { Walking at } \\
\text { differ- } \\
\text { ent speeds }\end{array}$ & $\begin{array}{l}\text { Mechanical } \\
\text { power }\end{array}$ & $\begin{array}{c}\text { Mechanical power asymmetry in these people is not af- } \\
\text { fected by the walking speed. It questions the prevailing } \\
\text { thinking about walking speed as a measure of the } \\
\text { patient's function }\end{array}$ & - \\
\hline $\begin{array}{l}\text { Hendrickson et } \\
\text { al., } 2014 \text { [39] }\end{array}$ & $\begin{array}{l}\text { Elderly subjects } \\
\text { with stroke }\end{array}$ & $\begin{array}{l}\text { Walking at } \\
\text { the desired } \\
\text { speed }\end{array}$ & Kinematics & $\begin{array}{l}\text { Reduced involvement of disturbed limbs for controlling } \\
\text { static balance is associated with spatial-temporal gait } \\
\text { asymmetry }\end{array}$ & - \\
\hline
\end{tabular}

PHYSICAL TREA T MENTS

similar clinical study has been conducted on subjects with lower limb dysfunction, for example, dysfunctions caused by Parkinson disease [19, 20, 40, 41], Huntington disease [40], Autism [31], stroke [17, 22, 23, 26, 30, 38, 39], lower limb amputation [14, 42, 43], length difference [15], bone fracture [2], joint arthroplasty [3, 44, 45], osteoarthritis $[5,21]$, and cerebral palsy $[8,46]$.

Based on the present research results, the lower limb dysfunction due to disease and anomalies affects and increases the gait asymmetry (Table 1 ). In this case, gait asymmetry is considered an important factor to evaluate the functional inefficiency of the patients with the anomaly. Thereby, achieving gait symmetry or reducing gait asymmetry in people with any disorder before and after rehabilitation has been used to assess the effectiveness of the treatment model [2-6]. In this context, the results of several studies have also shown the effectiveness of rehabilitation exercises [3, 30, 39, 47]. However, according to different results, healthy people's gait is also somewhat asymmetric $[1,9,10,20,28,32,33,35,37]$, that is caused by performing different functional tasks by the lower limbs [10].

Rehabilitation clinicians need simple ways to quantify various aspects of abnormal walking to determine individual compliance with bone-articular deficiency, dysfunction, or assessment of gait changes in the elderly [48]. In this case, various instruments have been developed which provides information on automatic or semi-automatic gait asymmetry $[49,50]$. The use of symmetry indices is also one of the most commonly used methods for measuring and interpreting it [11]. In this regard, several studies have compared commonly used symmetry indices and showed that none is preferred in terms of the ability to distinguish healthy subjects from people with anomaly or disease, although the symmetry ratio has been proposed because of its simplicity $[4,51]$. 


\section{The effect of movement speed on gait symmetry}

Since changes in horizontal speed have significant and well-documented effect on the biomechanical behavior of walking [52], a reasonable assumption is also the effect of speed on the extent of gait asymmetry [13]. These conditions have been tested in patients with anomalies affecting the lower limbs, and the results have shown that decreasing or increasing the movement speed relative to the desired or normal speed affects the performance of these individuals by increasing gait asymmetry $[15,22,33,53]$.

In this case, more time is spent on the foot with abnormality (for example, the prosthetic foot) when walking at slow speed relative to the normal speed; because the entire body weight must be supported at this phase, maintaing gait symmetry is getting difficult for the person [14, 54]. With regard to the high speed of walking in patients with the anomaly in the lower limb, the people may fail to move their abnormal feet desirably [33, 39]. Under these conditions, rehabilitation exercises with emphasis on improving dysfunctional limb are recommended [33, 54]. Based on this evidence, in evaluating the gait asym- metry of elderly or subjects with any disease or anomaly in the lower limb, movement speed should be considered as a control factor, too.

However, the results of several studies on kinematic variables and GRF in healthy subjects $[13,29,35]$ and people with lower limb malfunctions [17, 22, 53] showed that the increase in walking speed had no significant effect on gait asymmetry, and sometimes reduces it. Carpes et al. [55] in a review study on the reduced asymmetry in subjects when performing a task at a higher speed or power, argued that more research must be done on why gait asymmetry occurs in movements with normal speed and the kinematic symmetry occurs only in conditions with maximum effort. Hence, gait symmetry may not always be a desirable goal, and it can change according to the context of the task and subject. However, Goble et al. [13] justified this phenomenon using the theory of dynamic systems and motor control. There are various examples in this area where inter-limb coupling improves with increasing speed [56].
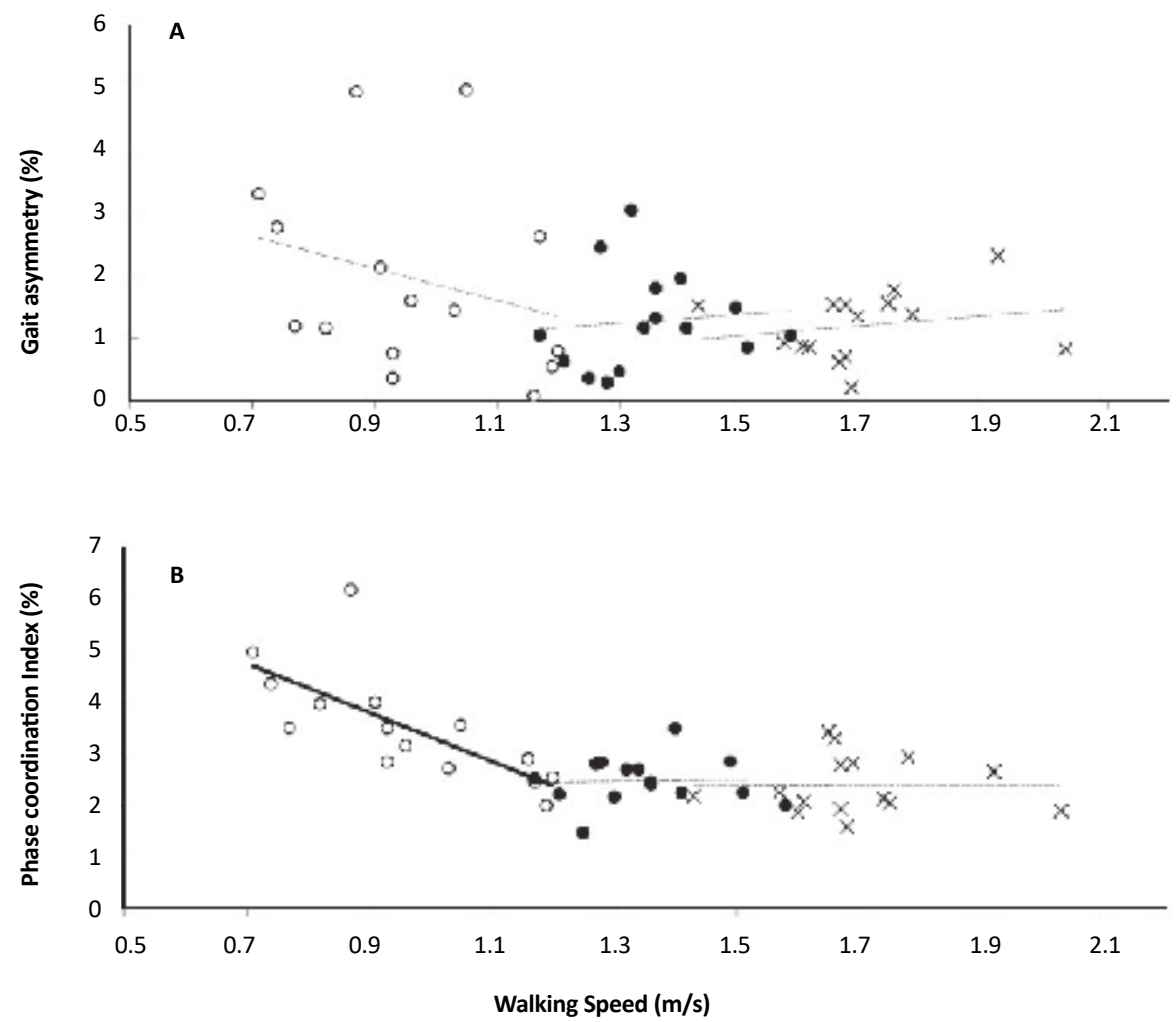

PHYSICAL TREA Y MENTS

Figure 2. Relationship between Gait Asymmetry (GA), Phase Coordination Index (PCI) and walking speed in 15 healthy individuals (7 men and 8 women with a imean(SD) age of 26.3(3.9) years). (A) For all subjects, the GA value is plotted for slow (left), normal (middle) and fast (right) walking speeds. Regression analysis showed no relationship between walking speed and GA for none of these conditions $\left(P \geq 0.286, R^{2} \leq 0.09\right)$. (B) For each subject, the $P C I$ is presented for three walking speeds, as in the previous diagram. 
Accordingly, the body segments act as pair oscillators, in which the symmetric relationships (in-phase and outphase) are more easily maintained at higher speeds than other complex phase conditions. For example, feet are more likely to experience non-coupling and apply different functional strategies at lower speeds, while motion patterns are carried out with higher coupling and symmetry at higher speeds [13]. This finding is consistent with Plotnik et al. [35] finding, that measured GRF for gait asymmetry. Based on the results of this study (Figure 2), although no relationship was observed between three walking speeds and gate asymmetry, a significant and inverse correlation existed between walking speed and Phase Coordination Index (PCI) at low speeds, i.e. increasing PCI was inversely related to decreasing speed.

PCI is, in fact, a factor for examining a combination of precision and coordination of the walking phase, where the lower values represent a more accurate and stable walking phase, and the higher values indicate a disorder in the lateral coordination of the limbs [20]. Also, these conditions may result from sending neural signals to higher centers of the nervous system and the need for more attention at lower walking speeds [35]. Regression analysis showed only a significant linear relationship between PCI and walking at slow speed $\left(\mathrm{P}=0.002, \mathrm{R}^{2}=0.53\right)$. Curve fitting showed that the following relationship is established between PCI and walking at slow speed:

$$
P C I=B+\text { walking speed } \times A
$$

, where $\mathrm{A}=-4.41 \pm 2.31$ and $\mathrm{B}=8.8 \pm 1.20$ (Dark thick line). No significant relationship was found for other speeds $\left(\mathrm{R}^{2}<0.09, \mathrm{P}>0.288\right)$ (derived from study [35]).

\section{The effect of age on gait symmetry}

In general, aging can affect walking; for example, young people walk faster, with a longer pace, and higher stepping rates than the elderly [57]. These changes in walking may result from degradation of neurological and physical performance due to aging [37]. Since gait symmetry depends on the nervous and physical function of the individual [1], it can be expected that it decreases by aging. However, studies have reported different results. Although several studies have shown that age is not effective on gait symmetry $[4,6,24,48]$, recent studies have reported otherwise, which seems to differ in the age distribution of subjects [20,36,37].

Contrary to study results of nonsignificant effect over a continuous age range $[4,24,48]$, some studies with significant effects $[36,37]$ compared two different age groups. Meanwhile, Himann et al. showed that gait function remains unchanged until the age of 60 , which then varies greatly [58]. This finding justifies the report on the insignificant effect of aging on gait symmetry in subjects over a continuous age range. Because aging, especially at the age of 60 and above, can affect gait symmetry, this factor should be considered in studies along with clinical examinations. However, because it is unclear that changes in the gait symmetry occur exactly at what age, further studies in this field seem essential.

\section{The effect of gender on gait symmetry}

Like age, gender also has a significant effect on human gait parameters. Usually, women walk slower and with shorter pace than men $[57,59]$. Also, previous studies have reported a significant difference between the sexes in terms of kinematic gait characteristics, including the range of motion in hip and ankle joints [60], as well as other parameters such as the mechanical energy of joints [59]. Accordingly, due to the morphological differences between two sexes, one can expect differences in the gait symmetry characteristics.

However, according to the conducted studies, the slight effect of gender on gait symmetry has not been clearly disclosed yet. Given that the gait symmetry indices used in the studies are different, several studies have reported non-significant gender effects on gait symmetry [4, 24, 48]. On the other hand, some papers have shown a significant sex-specific differences in terms of gait symmetry $[32,37]$. However, drawing a definite conclusion is impossible because of few studies in this regard. In the meantime, further studies aiming at more complex variables such as joint torque during walking can provide a more comprehensive insight into the characteristics of gait symmetry and the difference between the two sexes.

\section{Discussion}

Based on the results of various studies, walking is an asymmetric behavior regarding the different performance of the lower limbs. Having a disease and anomaly affecting the function of the lower limbs increases this asymmetry. In this regard, achieving full symmetry after a rehabilitation period cannot be hypothetical, although its reduction is desirable. It is unclear, however, that the degree of asymmetry in the function of the lower limbs in healthy people is as high as to be considered a criterion that necessitates further research.

Also, considering the probable effect of walking speed and age on gait symmetry, it is necessary to control these 
factors in future studies. Finally, such information can be useful for improving the performance of athletes, as well as for gait assessment, clinical prescriptions for patients with abnormalities, and design of orthosis and prosthesis.

\section{Acknowledgements}

This research did not receive any specific grant from funding agencies in the public, commercial, or not-forprofit sectors.

\section{Conflict of Interest}

The authors declared no conflicts of interest.

\section{References}

[1] Sadeghi H, Allard P, Prince F, Labelle H. Symmetry and limb dominance in able-bodied gait: A review. Gait \& Posture. 2000; 12(1):34-45. doi: 10.1016/s0966-6362(00)00070-9

[2] Becker HP, Rosenbaum D, Kriese T, Gerngro H, Claes L. Gait asymmetry following successful surgical treatment of ankle fractures in young adults. Clinical Orthopaedics and Related Research. 1995; 311:262-9. PMID: 7634584

[3] Hesse S, Werner C, Seibel H, von Frankenberg S, Kappel EM, Kirker S, et al. Treadmill training with partial body-weight support after total hip arthroplasty: A randomized controlled trial. Archives of Physical Medicine and Rehabilitation. 2003; 84(12):1767-73. doi: 10.1016/s0003-9993(03)00434-

[4] Patterson KK, Nadkarni NK, Black SE, McIlroy WE. Gait symmetry and velocity differ in their relationship to age. Gait \& Posture. 2012; 35(4):590-4. doi: 10.1016/j.gaitpost.2011.11.030

[5] Hodt Billington C, Helbostad JL, Vervaat W, Rognsvåg T, Moe Nilssen R. Criteria of gait asymmetry in patients with hip osteoarthritis. Physiotherapy Theory and Practice. 2011 28(2):134-41. doi: 10.3109/09593985.2011.574783

[6] Diop M, Rahmani A, Belli A, Gautheron V, Geyssant A, Cottalorda J. Influence of speed variation and age on the asymmetry of ground reaction forces and stride parameters of normal gait in children. Journal of Pediatric Orthopaedics B. 2004; 13(5):308-14. doi: 10.1097/01202412-200409000-00005

[7] Ellis RG, Howard KC, Kram R. The metabolic and mechanical costs of step time asymmetry in walking. Proceedings of the Royal Society B: Biological Sciences. 2013; 280(1756):20122784-20122784. doi: 10.1098/rspb.2012.2784

[8] Durham S, Eve L, Stevens C, Ewins D. Effect of functional electrical stimulation on asymmetries in gait of children with hemiplegic cerebral palsy. Physiotherapy. 2004; 90(2):82-90. Doi: 10.1016/j.physio.2004.02.003
[9] Sadeghi H. Local or global asymmetry in gait of people without impairments. Gait \& Posture. 2003; 17(3):197-204. doi: 10.1016/s0966-6362(02)00089-9

[10] Sadeghi H, Allard P, Duhaime M. Functional gait asymmetry in able bodied subjects. Human Movement Science. 1997; 16(2-3):243-58. doi: 10.1016/s0167-9457(96)00054-1

[11] Nasirzade A, Sadeghi H, Mokhtarinia HR, Rahimi A. Gait symmetry and its evaluation's methods: A review. Scientific Journal of Rehabilitation Medicine. 6(2):283-97.

[12] Raibert M. Symmetry in running. Science. 1986; 231(4743):1292-4. doi: 10.1126/science.3945823

[13] Goble D., Marino G., Potvin J. The influence of horizontal velocity on interlimb symmetry in normal walking. Human Movement Science. 2003; 22(3):271-83. doi: 10.1016/s01679457(03)00047-2

[14] Nolan L, Wit A, Dudziñski K, Lees A, Lake M, Wychowañski $M$. Adjustments in gait symmetry with walking speed in trans femoral and trans tibial amputees. Gait \& Posture. 2003; 17(2):142-51. doi: 10.1016/s0966-6362(02)00066-8

[15] Perttunen JR, Anttila E, Sodergard J, Merikanto J, Komi PV Gait asymmetry in patients with limb length discrepancy. Scandinavian Journal of Medicine and Science in Sports. 2004; 14(1):49-56. doi: 10.1111/j.1600-0838.2003.00307.x

[16] Chockalingam N, Dangerfield PH, Rahmatalla A, Ahmed EN, Cochrane T. Assessment of ground reaction force during scoliotic gait. European Spine Journal. 2004; 13(8):750-4. doi: 10.1007/s00586-004-0762-9

[17] Rodgers M, Forrester LW, Mizelle C, Harris Love ML. Effects of gait velocity on COP symmetry measures in individuals with stroke. Paper presented at: The $28^{\text {th }}$ Annual Meeting of the American Society of Biomechanics, 8 September 2004, Portland, Oregon, United States.

[18] Kramers de Quervain I, Muller R, Stacoff A, Grob D, Stussi E. Gait analysis in patients with idiopathic scoliosis. European Spine Journal. 2004; 13(5). doi: 10.1007/ s00586-003-0588-x

[19] Plotnik M, Giladi N, Balash Y, Peretz C, Hausdorff JM. Is freezing of gait in Parkinson's disease related to asymmetric motor function. Annals of Neurology. 2005; 57(5):656-63. doi: 10.1002/ana.20452

[20] Plotnik M, Giladi N, Hausdorff JM. A new measure for quantifying the bilateral coordination of human gait: Effects of aging and Parkinson's disease. Experimental Brain Research. 2007; 181(4):561-70. doi: 10.1007/s00221-007-0955-7

[21] Liikavainio T, Isolehto J, Helminen HJ, Perttunen J, Lepola V, Kiviranta I, et al. Loading and gait symmetry during level and stair walking in asymptomatic subjects with knee osteoarthritis: Importance of quadriceps femoris in reducing impact force during heel strike. The Knee. 2007; 14(3):231-8. doi: 10.1016/j.knee.2007.03.001

[22] Patterson KK, Parafianowicz I, Danells CJ, Closson V, Verrier MC, Staines WR, et al. Gait asymmetry in community ambulating stroke survivors. Archives of Physical Medicine and Rehabilitation. 2008; 89(2):304-10. doi: 10.1016/j. apmr.2007.08.142

[23] Hodt Billington C, Helbostad JL, Moe Nilssen R. Should trunk movement or footfall parameters quantify gait asym- 
metry in chronic stroke patients. Gait \& Posture. 2008; 27(4):552-8. doi: 10.1016/j.gaitpost.2007.07.015

[24] Senden R, Grimm B, Heyligers IC, Savelberg HHCM, Meijer K. Acceleration based gait test for healthy subjects: Reliability and reference data. Gait \& Posture. 2009; 30(2):192-6. doi: 10.1016/j.gaitpost.2009.04.008

[25] Bosch K, Rosenbaum D. Gait symmetry improves in childhood -A 4-year follow-up of foot loading data. Gait \& Posture. 2010; 32(4):464-8. doi: 10.1016/j.gaitpost.2010.07.002

[26] Patterson KK, Gage WH, Brooks D, Black SE, McIlroy WE. Evaluation of gait symmetry after stroke: A comparison of current methods and recommendations for standardization. Gait \& Posture. 2010; 31(2):241-6. doi: 10.1016/j.gaitpost.2009.10.014

[27] Seeley MK, Umberger BR, Clasey JL, Shapiro R. The relation between mild leg length inequality and able bodied gait asymmetry. Journal of Sports Science and Medicine. 2010; 9(4):572-9. PMCID: PMC3761822

[28] Kong PW, Beauchamp G, Suyama J, Hostler D. Effect of fatigue and hypohydration on gait characteristics during treadmill exercise in the heat while wearing firefighter thermal protective clothing. Gait \& Posture. 2010; 31(2):284-8. doi: 10.1016/j.gaitpost.2009.11.006

[29] Lythgo N, Wilson C, Galea MP. Gait symmetry in school aged children and young adults whilst walking at slow, normal and fast speeds. Paper presented at: The $6^{\text {th }}$ World Congress of Biomechanics (WCB 2010), 1-6 August 2010, Singapore. 2010; 178-81. doi: 10.1007/978-3-642-14515-5_46

[30] Bradley CE, Wutzke CJ, Zinder S, Lewek MD. Spatiotemporal gait asymmetry is related to balance/fall risk in individuals with chronic stroke. Gainesville: American Society of Biomechanics; 2012.

[31] Chester VL, Calhoun M. Gait symmetry in children with autism. Autism Research and Treatment. 2012; 2012:1-5. doi: $10.1155 / 2012 / 576478$

[32] Forczek W, Staszkiewicz R. An evaluation of symmetry in the lower limb joints during the able bodied gait of women and men. Journal of Human Kinetics. Walter de Gruyter GmbH; 2012; 35(1):47-57. doi: 10.2478/v10078-012-0078-5

[33] Laroche DP, Cook SB, Mackala K. Strength asymmetry increases gait asymmetry and variability in older women. Medicine \& Science in Sports \& Exercise. 2012; 44(11):217281. doi: $10.1249 / \mathrm{mss} .0 \mathrm{~b} 013 \mathrm{e} 31825 \mathrm{e} 1 \mathrm{~d} 31$

[34] Winiarski S, Czamara A. Evaluation of gait kinematics and symmetry during the first two stages of physiotherapy after anterior cruciate ligament reconstruction. Acta of Bioengineering \& Biomechanics. 2012; 14(2):91-100. PMID: 22794132

[35] Plotnik M, Bartsch RP, Zeev A, Giladi N, Hausdorff JM. Effects of walking speed on asymmetry and bilateral coordination of gait. Gait \& Posture. 2013; 38(4):864-9. doi: 10.1016/j. gaitpost.2013.04.011

[36] Kobsar D, Olson C, Paranjape R, Hadjistavropoulos T, Barden JM. Evaluation of age related differences in the stride to stride fluctuations, regularity and symmetry of gait using a waist mounted tri axial accelerometer. Gait \& Posture. 2014; 39(1):553-7. doi: 10.1016/j.gaitpost.2013.09.008
[37] Kobayashi H, Kakihana W, Kimura T. Combined effects of age and gender on gait symmetry and regularity assessed by autocorrelation of trunk acceleration. Journal of Neuro Engineering and Rehabilitation. 2014; 11(1):109. doi: 10.1186/1743-0003-11-109

[38] Mahon CE, Farris DJ, Sawicki GS, Lewek MD. Individual limb mechanical analysis of gait following stroke. Journal of Biomechanics. 2015; 48(6):984-9. doi: 10.1016/j.jbiomech.2015.02.006

[39] Hendrickson J, Patterson KK, Inness EL, Mcllroy WE, Mansfield A. Relationship between asymmetry of quiet standing balance control and walking post stroke. Gait \& Posture. 2014; 39(1):177-81. doi: 10.1016/j.gaitpost.2013.06.022

[40] Hausdorff JM, Cudkowicz ME, Firtion R, Wei JY, Goldberger AL. Gait variability and basal ganglia disorders: Stride to stride variations of gait cycle timing in parkinson's disease and Huntington's disease. Movement Disorders. 1998; 13(3):428-37. doi: 10.1002/mds.870130310

[41] Sant'Anna A, Salarian A, Wickstrom N. A new measure of movement symmetry in early Parkinson's disease patients using symbolic processing of inertial sensor data. IEEE Transactions on Biomedical Engineering. 2011; 58(7):212735. doi: 10.1109/tbme.2011.2149521

[42] Ganguli S, Mukherji P, Bose KS. Gait evaluation of unilateral below knee amputees fitted with patellar tendon bearing prostheses. Journal of the Indian Medical Association. 1974; 63(8):256-9.

[43] Mattes SJ, Martin PE, Royer TD. Walking symmetry and energy cost in persons with unilateral transtibial amputations: Matching prosthetic and intact limb inertial properties. Archives of Physical Medicine and Rehabilitation. 2000 81(5):561-8. doi: 10.1016/s0003-9993(00)90035-2

[44] Lugade V, Wu A, Jewett B, Collis D, Chou LS. Gait asymmetry following an anterior and anterolateral approach to total hip arthroplasty. Clinical Biomechanics. 2010; 25(7):675-80. doi: $10.1016 /$ j.clinbiomech.2010.05.003

[45] McCrory JL, White SC, Lifeso RM. Vertical ground reaction forces: Objective measures of gait following hip arthroplasty. Gait \& Posture. 2001; 14(2):104-9. Doi: 10.1016/ s09666362(01)00140-0

[46] Böhm H, Döderlein L. Gait asymmetries in children with cerebral palsy: Do they deteriorate with running. Gait \& Posture. 2012; 35(2):322-7. doi: 10.1016/j.gaitpost.2011.10.003

[47] Kahn JH, Hornby TG. Rapid and long term adaptations in gait symmetry following unilateral step training in people with hemiparesis. Physical Therapy. 2009; 89(5):474-83. doi: 10.2522/ptj.20080237

[48] Auvinet B, Berrut G, Touzard C, Moutel L, Collet N, Chaleil D, et al. Reference data for normal subjects obtained with an accelerometric device. Gait \& Posture. 2002; 16(2):124-34. Doi: 10.1016/s0966-6362(01)00203-x

[49] Bamberg SJM, Carson RJ, Stoddard G, Dyer PS, Webster JB. The lower extremity ambulation feedback system for analysis of gait asymmetries: Preliminary design and validation results. JPO Journal of Prosthetics and Orthotics. 2010; 22(1):31-6. doi: 10.1097/jpo.0b013e3181ccc065 
[50] Draper ERC. A treadmill based system for measuring symmetry of gait. Medical Engineering \& Physics. 2000; 22(3):215-22. doi: 10.1016/s1350-4533(00)00026-6

[51] Błażkiewicz MI, Wiszomirska I, Wit AN. Comparison of four methods of calculating the symmetry of spatial temporal parameters of gait. Acta of Bioengineering and Biomechanics. 2014; 16(1):29-35. PMID: 24708092

[52] Perry J, Burnfield JM. Gait analysis: Normal and pathological function. New Jersey: SLACK Incorporated; 2010.

[53] Donker SF, Beek PJ. Interlimb coordination in prosthetic walking: Effects of asymmetry and walking velocity. Acta Psychologica. 2002; 110(2-3):265-88. doi: 10.1016/s00016918(02)00037-9

[54] Schaarschmidt M, Lipfert SW, Meier Gratz C, Scholle HC, Seyfarth A. Functional gait asymmetry of unilateral transfemoral amputees. Human Movement Science. 2012; 31(4):907-17. doi: 10.1016/j.humov.2011.09.004

[55] Carpes FP, Mota CB, Faria IE. On the bilateral asymmetry during running and cycling: A review considering leg preference. Physical Therapy in Sport. 2010; 11(4):136-42. doi: 10.1016/j.ptsp.2010.06.005

[56] Beek PJ, Peper CE, Stegeman DF. Dynamical models of movement coordination. Human Movement Science. 1995; 14(4-5):573-608. doi: 10.1016/0167-9457(95)00028-5

[57] Prince F, Corriveau H, Hébert R, Winter DA. Gait in the elderly. Gait \& Posture. 1997; 5(2):128-35.

[58] Himann JE, Cunningham DA, Rechnitzer PA, Paterson DH. Age related changes in speed of walking. Medicine \& Science in Sports \& Exercise. 1988 ; 20:161-6. doi: 10.1249/00005768198804001-00010

[59] Allard P, Lachance R, Aissaoui R, Sadeghi H, Duhaime M. Able bodied gait in men and women. In: Allard P, Cappozzo A, Lundberg ACV, editors. Three Dimensional Analysis of Human Locomotion. Canada: John Wiey \& Sons; 1997.

[60] Ko S, Tolea MI, Hausdorff JM, Ferrucci L. Sex specific differences in gait patterns of healthy older adults: Results from the Baltimore longitudinal study of aging. Journal of Biomechanics. 2011; 44(10):1974-9. doi: 10.1016/j.jbiomech.2011.05.005 